\title{
Oxidative Status of Saliva and Plasma in Diabetic Children
}

\author{
${ }^{1}$ Selma Porovic, ${ }^{2}$ Hrvoje Juric, ${ }^{3}$ Senka M Dinarevic
}

\begin{abstract}
Aim: The objective of this study was to determine the oxidative status of saliva and plasma in diabetic children, by analyzing advanced oxidation protein products (AOPPs) and total antioxidant capacity (TAC).
\end{abstract}

Materials and methods: Study included 60 patients with diabetes mellitus type I (DMT1) aged $12.45 \pm 2.65$ years, and 40 healthy age-matched controls. The AOPP and TAC of the plasma and saliva samples were determined using a commercial QuantiChrom ${ }^{\text {TM }}$ Antioxidant Assay Kit (DTAC-100) for TAC determination, and Immunodiagnostic AG [enzyme-linked immunosorbent assay kit for AOPP].

Results: Values of salivary and plasma AOPP were lower in diabetic patients than in healthy controls, while value of TAC was clinically and significantly higher in plasma of controls, and clinically higher in saliva of healthy control group, compared with diabetic patients. Average value of hemoglobin A1c (HbA1c) was $7.58 \pm 0.85 \%$.

Conclusion: Results of this study showed that diabetes mellitus as a condition, with well-controlled $\mathrm{HbA} 1 \mathrm{c}$, has no influence on AOPP levels in saliva and plasma, while TAC levels of saliva and plasma are lower in diabetic patients, which means that DMT1 has an influence on the TAC.

Keywords: Advanced oxidation protein products, Children, Diabetes, Oxidative status, Plasma, Saliva, Total antioxidant capacity.

How to cite this article: Porovic S, Juric H, Dinarevic SM. Oxidative Status of Saliva and Plasma in Diabetic Children. Donald School J Ultrasound Obstet Gynecol 2017;11(2):169-173.

Source of support: Nil

Conflict of interest: None

\section{INTRODUCTION}

Type I diabetes mellitus (DMT1) is a chronic illness characterized by the body's inability to produce insulin due to the autoimmune destruction of the beta cells in the pancreas. Onset most often occurs in childhood, but

\footnotetext{
${ }^{1}$ Postgraduate Student, ${ }^{2}$ Professor, ${ }^{3}$ Academician

${ }^{1}$ Department of Preventive and Pediatric Dentistry, Public Health Center of Sarajevo Canton, Sarajevo, Bosnia and Herzegovina

${ }^{2}$ Department of Pediatric and Preventive Dentistry, School of Dental Medicine, University of Zagreb, Zagreb, Croatia

${ }^{3}$ Academy of Sciences and Arts of Bosnia and Herzegovina Sarajevo, Bosnia and Herzegovina

Corresponding Author: Selma Porovic, Postgraduate Student Department of Preventive and Pediatric Dentistry, Public Health Center of Sarajevo Canton, Sarajevo, Bosnia and Herzegovina Phone: +38733292500, e-mail: selma.porovic@gmail.com
}

the disease can also develop in adults in their late 30s and 40 s. $^{1}$

Oxidative stress is central to the development of insulin resistance and diabetic complications. Oxidative stress plays a critical role in diabetic complications. Hyperglycemia leads to the overproduction of superoxides in mitochondria, and this increase in superoxide production activates several pathways that contribute to diabetic complications. ${ }^{2}$ Hyperglycemia may directly cause increased generation of reactive oxygen species (ROS). Glucose undergoes auto-oxidation, which creates - $\mathrm{OH}$ radicals. Additionally, glucose nonenzymatically reacts with proteins, making Amadori products, which is followed by increased levels of AGEs. ${ }^{3}$

There is currently great interest in the potential role of increased oxidative stress in the development of diabetic complications. In patients with diabetes, oxidative stress seems to be caused by both increased production of plasma ROS and reduction of antioxidant defenses, with a consequent increase in lipid peroxidation and oxidized low-density lipoproteins (LDLs), which are more atherogenic than native LDLs. ${ }^{4}$

Plasma proteins, predominantly albumin and fibrinogen, undergo molecular modifications by oxidation, which can be measured as AOPPs, which were first identified by Witko-Sarsat et al as efficient oxidative stress biomarkers in uremic patients. ${ }^{5}$

The AOPPs are produced by the reaction between the chlorophora glycosides (HOCI/OCI-), neutrophil derivatives, and proteins, and are defined as cross-product dithyrosine protein. Increased AOPP levels indicate oxidative damage to protein. ${ }^{6}$

The TAC is a sum of endogenous and exogenous antioxidant systems. All systems involved in antioxidant activity act together and contribute to a better defense of the body toward oxidative stress. Because of this positive effect of some antioxidant systems, measurement of TAC gives a better insight into overall antioxidant activity. ${ }^{7,8}$

Research has shown that oxidative stress in diabetes is a cause, but, at the same time, the consequence of genesis and pathogenesis of diabetes. Oxidative stress has been demonstrated in the initial stage of diabetes and progressively increases with the development of the disorder. ${ }^{9}$

The aim of this study was to determine if there is a difference in salivary and plasma levels of AOPP and TAC in diabetic patients compared with healthy controls. 


\section{MATERIALS AND METHODS}

The study included 60 children with DMT1 aged 8 to 18 years, and 40 healthy age-matched controls. The study was approved by ethical committee of Clinical Health Center of Zagreb, Croatia, where plasma and saliva samples were conducted. Written consent for the participation of children was obtained from their parents. Blood samples were collected from the cubital vein. Blood was centrifuged at $4,000 \mathrm{rpm}$ for 10 minutes. Plasma samples were stored at $-80^{\circ} \mathrm{C}$. Tubes for vein collecting had heparin as anticoagulant (Vacuette, Greiner Bio-One, $\mathrm{SAD})$. Samples of unstimulated saliva were collected and centrifuged at $4,000 \mathrm{rpm}$ and stored at $-80^{\circ} \mathrm{C}$ until the moment of determination of AOPP and TAC. Plasma and saliva AOPP concentration was determined by ELISA method, using commercial kits of Immunodiagnostic AG (ELISA Kit for AOPPs). The measurement principle is based on the spectroscopic analysis of modified proteins at a wavelength of $340 \mathrm{~nm}$.

The absorbance was red on the microplate reader (STATFAX 2100, USA). The TAC of saliva and serum was determined by colorimeter, using QuantiChrom ${ }^{\mathrm{TM}}$ Antioxidant Assay Kit (DTAC-100). The method is based on $\mathrm{Cu} 2+$ reduction to $\mathrm{Cu}+$ by means of antioxidants in saliva or plasma samples. The resulting $\mathrm{Cu}+$ forms a colored complex whose intensity is read at $570 \mathrm{~nm}$. The color intensity is proportional to the TAC of saliva or plasma. The absorbance is read on the Microplate Reader (STAT FAX2100, USA) reader. The values are determined in $\mu \mathrm{m}$ Trolox equivalents. ${ }^{10}$

\section{Statistical Analysis}

The results are presented as mean $(x)$ and standard deviation (SD). Mann-Whitney's U test was used to test the significance of differences in continuous variables among the examined groups. The degree of correlation for the specified variables was determined by the Spearman method. A suitable multiple regression analysis model was used to determine the possible independent correlation of the examined variables. The value of $p<0.05$ was taken as statistically significant. For all statistical analyses, Statistical Package for the Social Sciences for Windows, version 16.0 was used. Based on the interval and the level of reliability, in correlation with the population with DMT1 in the area where the study was conducted, all based on Prism Research, the size of sample 60:40 was statistically relevant.

\section{RESULTS}

The study included 100 examinees divided into experimental group (children with DMT1) and healthy control group. Experimental group covered 60 examinees, while control group had 40 examinees. Experimental group had $50 \%$ males and the same number of females.

The control group had the same statistical ratio. Using analysis of variance test, no statistically significant difference in the mean age of the examined subjects was established ( $\mathrm{F}=0.014 ; \mathrm{p}=0.905)$. The average age of the experimental group was $12.51 \pm 2.78$ years (the oldest 18 years, the youngest 8 years). The mean age of the control group was $12.45 \pm 2.65$ years (the oldest 17 years, the youngest 8 years). The mean value of hemoglobin $\mathrm{A} 1 \mathrm{c}(\mathrm{HbA1c})$ in the blood of the experimental group was $7.58 \pm 0.85 \%$.

There was no statistically significant difference in the average values of advanced plasma protein oxidation products compared with the investigated groups $(\mathrm{F}=2.272 ; \mathrm{p}=0.135) ;$ however, a clinically significant difference was established. The mean plasma AOPP value of the experimental group was $8,801.02 \pm 2,373.94 \mathrm{ng} / \mathrm{mL}$, and in the control group, the clinically significant increase was $9,581.28 \pm 2,680.78 \mathrm{ng} / \mathrm{mL}$ (Table 1 ).

There was statistically and clinically significant difference in the average values of advanced oxidation products of saliva protein compared with the investigated groups $(\mathrm{F}=4.628, \mathrm{p}=0.034)$. The mean AOPP score of the subjects in the experimental group was $6,170.95 \pm 2,744.42 \mathrm{pg} / \mathrm{mL}$, and in the control group, subjects were statistically significant to a higher degree and it was 7,332.12 $\pm 2,464.24$ $\mathrm{pg} / \mathrm{mL}$ (Table 2).

Table 1: Average values of AOPPs in plasma

\begin{tabular}{|c|c|c|c|c|c|c|}
\hline & $N$ & $x$ & $S D$ & SEM & Minimun & Maximum \\
\hline Experimental group & 60 & 8801,02 & 2373,94 & 306,47 & 2910,20 & 14714,60 \\
\hline \multirow[t]{2}{*}{ Control group } & 40 & 9581,28 & 2680,78 & 438,88 & 5094,10 & 14750,40 \\
\hline & & & & & \multicolumn{2}{|c|}{$F=2,272 ; p=0,135$} \\
\hline
\end{tabular}

Table 2: Average values of AOPPs in saliva

\begin{tabular}{llllllr}
\hline & $N$ & $X$ & $S D$ & $S E M$ & Minimun & Maximum \\
\hline Experimental group & 60 & 6170,95 & 2744,42 & 357,29 & 1289,60 & 10000,00 \\
Control group & 40 & 7332,12 & 2464,24 & 389,63 & $1108,30 \quad 10000,50$ \\
& & & & & $\mathrm{~F}=4,628 ; \mathrm{p}=0,034$ \\
\hline
\end{tabular}


Oxidative Status of Saliva and Plasma in Diabetic Children

Table 3: Average values of TAC in plasma

\begin{tabular}{llllllr}
\hline & $N$ & $X$ & $S D$ & $S E M$ & Minimun & Maximum \\
\hline Experimental group & 60 & 317,79 & 67,73 & 8,74 & 188,40 & 469,90 \\
Control group & 40 & 372,60 & 66,50 & 10,78 & 248,50 & 551,00 \\
& & & & & $F=15,450 ; p=0,001$ \\
\hline
\end{tabular}

Table 4: Average values of TAC in saliva

\begin{tabular}{lllllrr}
\hline & $N$ & $X$ & $S D$ & SEM & Minimun & Maximum \\
\hline Experimental group & 60 & 104,33 & 80,71 & 10,50 & $-45,32$ & 328,23 \\
Control group & 40 & 115,91 & 46,20 & 18,37 & $-10,02$ & 549,17 \\
& & & & & $\mathrm{~F}=0,343 ; \mathrm{p}=0,560$ \\
\hline
\end{tabular}

Table 5: Correlation between $\mathrm{HbA} 1 \mathrm{c}$ values, age of respondents, and AOPP and TAC values in plasma and saliva of experimental group

\begin{tabular}{|c|c|c|c|c|c|c|c|}
\hline Group & & & Age & $A O P P p$ & AOPPs & TAKp & TAKs \\
\hline \multirow[t]{3}{*}{ Experimental } & $\mathrm{HbA1c}$ & Rho & $.414^{\mathrm{a}, \star \star}$ & $.123^{a, \star \star}$ & $.777^{a, \star *, *}$ & $.304^{a, \star \star}$ & $.173^{a, \star \star}$ \\
\hline & & $p$ & .234 & .735 & .008 & .392 & .633 \\
\hline & & $\mathrm{N}$ & 60 & 60 & 60 & 60 & 60 \\
\hline
\end{tabular}

"a"- level of significance $(p<0.05)$

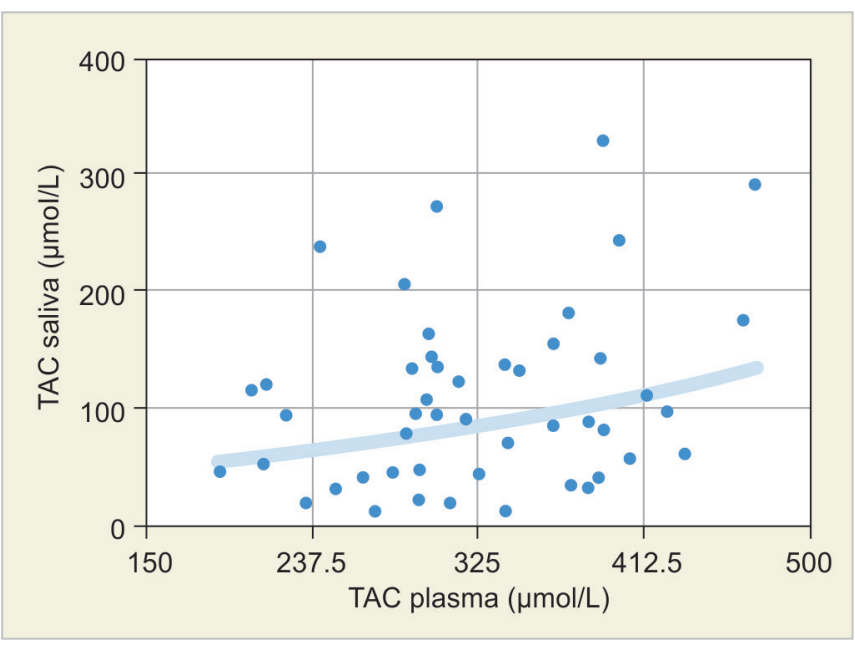

Graph 1: Correlation relations of TAC in saliva and plasma in subjects of the experimental group

A statistically and clinically significant difference in the mean TAC in plasma compared with the investigated groups $(F=15.450 ; p=0.001)$ was established. The mean value of TAC in the plasma of the subjects in the experimental group was $317.79 \pm 67.73 \mu \mathrm{mol} / \mathrm{L}$ and in the control group, it was statistically significantly higher and was $372.60 \pm 66.50 \mu \mathrm{mol} / \mathrm{L}$ (Table 3).

Although no statistically significant difference in the mean TAC in saliva compared with the investigated groups ( $\mathrm{F}=15.450 ; \mathrm{p}=0.001)$ was found, clinically, the control group respondents had a higher TAC value. The average value of TAC in the experimental group was $104.33 \pm 80.71 \mu \mathrm{mol} / \mathrm{L}$, and in the control group, the clinical significance was higher at $115.91 \pm 46.20 \mu \mathrm{mol} / \mathrm{L}$ (Table 4).

Using Spearman's correlation with AOPP and TAC values in plasmas and pigs and the age of subjects in both

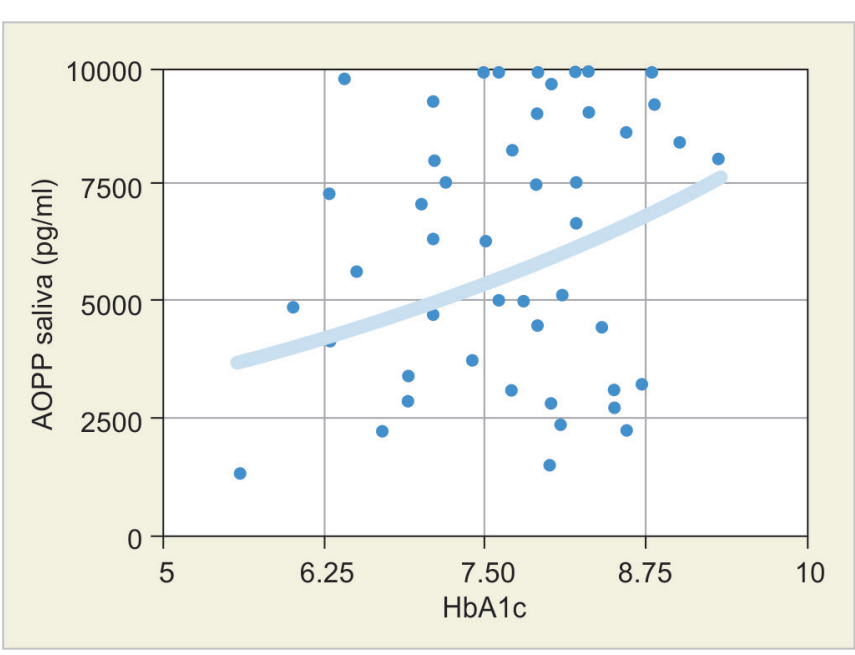

Graph 2: Correlation of $\mathrm{HbA} 1 \mathrm{c}$ value and AOPP values in the saliva of experimental group

study groups, a statistically significant positive correlation was found in TAC values in plasma and saline in the experimental group $(\mathrm{rho}=0.671, \mathrm{p}=0.034)$, while in other parameters and in relation to both groups we did not establish a statistically significant correlation (Graph 1).

Statistical analysis of the correlation of $\mathrm{HbA} 1 \mathrm{c}$ in the experimental group showed a statistically significant positive correlation between $\mathrm{HbA} 1 \mathrm{c}$ and AOPP values in saliva, rho $=0.777 ; \mathrm{p}=0.008$ (Table 5, Graph 2).

\section{DISCUSSION}

The lower values of AOPP in the experimental group in this study can be explained by the fact that most of the $\mathrm{HbA1c}$ subjects were within normal limits, so that the mean $\mathrm{HbA} 1 \mathrm{c}$ score was $7.58 \pm 0.85 \%$; the fact was that children had diabetes mellitus or their parents/guardians were diabetic, and they, thus, paid more attention to the 
quality of nutrition, and, in turn, had more input of antioxidants that affected plasma AOPP levels. In the studies available, higher values of plasma AOPP serum serotype in DMT1 patients and those of type II diabetes mellitus compared with healthy subjects were recorded. ${ }^{11-14}$ What is characteristic of the above-mentioned research is that the respondents are older than the subjects in our research, and the $\mathrm{HbA} 1 \mathrm{c}$ level in the investigators in the above-mentioned studies is also higher.

In the research of Pilar Martín-Gallán et al. From Barcelona who analyzed the plasma AOPP level in patients with DMT1 with and without complications, compared with the healthy control group, also recorded a higher plasma AOPP level in diabetic patients compared to the healthy control group and the correlation of $\mathrm{HbA} 1 \mathrm{c}$ level And the height of AOPP was not recorded. ${ }^{15}$

The saliva is a combination of gingival cervical fluid, whose composition is similar to serum, and fluid released from the salivary glands. In correlation with the composition of saliva, the finding of lower values of AOPP in the experimental group was expected, since such finding was in plasma. ${ }^{16}$

Statistical analysis of correlation $\mathrm{HbA1c}$ in the experimental group showed a statistically significant positive correlation between $\mathrm{HbA} 1 \mathrm{c}$ and AOPP in saliva, Diabetic hyperglycemia by the free radical production process, causing glication and oxidative degeneration of proteins. The emergence of alteration in function and structure of antioxidant protein enzymes can be due to non-enzymatic glitches, so detoxification of free radicals increases oxidative stress in diabetes. ${ }^{17}$

This study showed statistically and clinically significant difference in the mean values of TAC in plasma relative to the investigated groups. The results of our research correlated with the vast majority of available studies, where TAC in diabetic patients decreased compared to healthy subjects, ${ }^{18}$ as well as the researches mentioned in, the review article, reduced plasma TAC values In persons with DMT1. In the research Đorđrvić et al, TAC values were not significantly correlated with glucose metabolism markers (glycemia and HbA1C), nor with the duration of the disease. This is explained by time-dependent changes in individual constituents of TAC, as described in litherature, especially when it comes to antioxidant enzymes, which can also be reflected in total antioxidant status. ${ }^{19}$

By analyzing the TAC in saliva, no statistically significant difference was found in mean values compared to the investigated groups, clinically, the control group respondents had a higher value of TAC. In Pendyal et al, ${ }^{20}$ which describes increased salivary TAC in women with gestational diabetes but is also characterized by increased carious activity, which may be associated with increased salivary TAC in this test group. Also in the research carried out by Reznick et al, The results showed that oxidative stress in diabetic patients was accompanied with increased TAC in bile and blood. ${ }^{21}$

Using Spearman's correlation with TAC values in plasma and stomach and on the age of subjects in both study groups, a statistically significant positive correlation was found in the TAC values in plasma and saline in the experimental group. Statistical analysis of the relationship between $\mathrm{HbA} 1 \mathrm{c}$ and saline and plasma TAC showed no correlation. In the research of Pieme et $\mathrm{al}^{22}$ with the increase in glycolysis $\mathrm{HbA} 1 \mathrm{c}$, a decrease in TAC values was observed.

\section{CONCLUSION}

Results of this study showed that diabetes mellitus as a condition with well-controlled $\mathrm{HbA} 1 \mathrm{c}$ has no influence on AOPP levels in saliva and plasma, while TAC levels of saliva and plasma are lower in diabetic patients, which means that DMT1 has influence on TAC.

\section{REFERENCES}

1. Aathira R, Jain V. Advances in management of type 1 diabetes mellitus. World J Diabetes 2014 Oct 15;5(5):689-696.

2. $\mathrm{Wu}$ YY, Xiao E, Graves DT. Diabetes mellitus related bone metabolism and periodontal disease. Int J Oral Sci 2015 Jun 26;7(2):63-72.

3. Radenković SP. Evaluacija uticaja terapije insulinskim analozima na parametre oksidativnog stresa kod bolesnika sa dijabetes melitusom tip 1. Doktorska Disertacija, Niš: Medicinski Fakultet, 2014.

4. Marra G, Cotroneo P, Pitocco D, Manto A, Di Leo MA, Rautolo V, Caputo S, Giardina B, Ghirlanda G, Santini SA. Early increase of oxidative stress and reduced antioxidant defenses in patients with uncomplicated type 1 diabetes. Diabetes Care 2002 Feb;25(2):370-375.

5. Witko-Sarsat V, Friedlander M, Capeillere-Blandin C, NguyenKhoa T, Nguyen AT, Zingraff J, Jungers P, Descamps-Latscha $\mathrm{B}$ : Advanced oxidation protein products as a novel marker of oxidative stress in uremia. Kidney Int. 1996,49:1304-1313

6. Baskol M, Baskol G, Koc D, Ozbakir O, Yucesoy M. Advanced oxidation protein products a novel marker of oxidative stress in ulcerative colitis. J Clin Gastroenterol 2008 Jul;42(6):687-691.

7. Lobo V, Patil A, Phatak A, Chandra N. Free radicals, antioxidants and functional foods: impact on human health. Pharmacogn Rev 2010 Jul;4(8):118-126.

8. Kusano C, Ferrari B. Total antioxidant capacity: a biomarker in biomedical and nutrition studies. J Cell Mol Biol 2008;7(1):1-15.

9. Nikolić $\mathrm{D}$, Stanimirović J, Bjelogrlić P, Isenović RE. Oxidative stress and the role of antioxidative treatment in diabetes mellitus. Oxid Antioxid Med Sci 2014;3(1):9-14.

10. Katz PP, Wirthlin MR, Szpunar SM, Selby JV, Sepe SJ, Showstack JA. Epidemiology and prevention of periodontal disease in individuals with diabetes. Diabetes Care 1991 May;14(5):375-385. 
11. Abou-Seif MA, Youssef AA. Evaluation of some biochemical changes in diabetic patients. Clin Chim Acta 2004 Aug 16;346(2):161-170.

12. Kalousová M, Škrha J, Zima T. Advanced glycation endproducts and advanced oxidation protein products in patients with diabetes mellitus. Physiol Res 2002;51(6):597-604.

13. Kural A, Toker A, Seval H, Döventaş Y, Basınoğlu F, Koldaş M, Sağlam ZA. Advanced glycation end-products and advanced oxidation protein products in patients with insulin dependent diabetes mellitus and first degree relatives. Med J Bakirkoy 2011 Dec;7(4):130-135.

14. Mohammedi K, Bellili-Muñoz N, Driss F, Roussel R, Seta N, Fumeron F, Hadjadj S, Marre M, Velho G. Manganese superoxide dismutase (SOD2) polymorphisms, plasma advanced oxidation protein products (AOPP) concentration and risk of kidney complications in subjects with type 1 diabetes. PLoS One 2014 May;9(5):e96916.

15. Martín-Gallán P, Carrascosa A, Gussinyé M, Domínguez C. Biomarkers of diabetes-associated oxidative stress and antioxidant status in young diabetic patients with or without subclinical complications. Free Radic Biol Med 2003 Jun 15;34(12):1563-1574.

16. Krysińska A, Wojnar M, Hermanowicz A, Matuszczak E. The role of saliva in the process of oxidative stress - review of literature. J Educ Health Sport 2016;6(12):730-738.
17. Asmat U, Abad K, Ismail K. Diabetes mellitus and oxidative stress - a conciese review. Saudi Pharm J 2016 Sep;24(5):547-553.

18. Patil VS, Patil VP, Gokhale N, Acharya A, Kangokar P. Chronic periodontitis in type 2 diabetes mellitus: oxidative stress as a common factor in periodontal tissue injury. J Clin Diagn Res 2016 Apr;10(4):BC12-BC16.

19. Đorđrvić G, Durić S, Apostolskit S, Dordević V, Zivković M. Total antioxidant blood capacity in patients with type 2 diabetes mellitus and distal symmetrical polyneuropathy. Vojnosanit Pregl 2008 Sep;65(9):663-669.

20. Pendyala G, Thomas B, Joshi SR. Evaluation of Total Antioxidant Capacity of Saliva in Type 2 Diabetic Patients with and without Periodontal Disease: A Case-Control Study. N Am J Med Sci. 2013;5(1): 51-57.

21. Reznick AZ, Shehadeh N, Shafir Y, Nagler RM. Free radicals related effects and antioxidants in saliva and serum of adolescents with type 1 diabetes mellitus. Arch Oral Biol 2006 Aug;51(8):640-648.

22. Pieme CA, Tatangmo JA, Simo G, Biapa Nya PC, Ama Moor VJ, Moukette Moukette B, Tankeu Nzufo F, Njinkio Nono BL, Sobngwi E. Relationship between hyperglycemia, antioxidant capacity and some enzymatic and non-enzymatic antioxidants in African patients with type 2 diabetes. BMC Res Notes 2017 Mar 29;10(1):141. 